higher than the rate for residents in rural areas. Tuberculosis mortality has decreased continuously since the beginning of the century, the rate in 1941 being less than one fourth that in 1900, and has fallen at a greater rate than mortality from all causes.

\section{Commercial Fish Catch of California for and 1942}

1941

Fish Bulletin No. 59 of the California Department of Natural Resources, Division of Fish and Game, Bureau of Marine Fisheries (1944), by the staff of the Bureau, contains detailed records of fish delivered by commercial fishing boats to Californian ports. In addition, shipments of fresh fish by truck, rail or cargo vessel to Californian factories from outside the State are included. There is much information in this report. The value of all landings is tabulated, the 1942 values reflecting the higher war prices and price-ceilings fixed by the Federal Government. Although the value is much increased, the weight in pounds is less. The decrease in volume of the 1942 catch was due to reduced numbers of the better class of fishing boats and of experienced fishermen, as well as to the restrictions placed upon the free movement of fishing vessels necessitated by Army and Navy coastal defence plans. The sardine. Sardinopsis ccerulea, heads the list both in weight and value; the Pacific mackerel, Pneumatophorus diego, and the yellow tuna, Neothunnus macropterus, coming next. Various shell-fish occur in much smaller numbers. It is interesting to note that crabs (Cancer magister) average $2 \mathrm{lb}$. each and abalones (Haliotis spp.) $50 \mathrm{lb}$. per dozen. A useful list of common and specific names of fishes, crustaceans and molluses is given.

\section{Soil Conservation in Kenya}

IN his first broadcast, on December 27, since he assumed office as governor of Kenya, Sir Philip Mitchell dealt with one of the Colony's most pressing problems-soil erosion. He illustrated his talk by reference to the Ukamba Reserve, where the faradvanced state of soil deterioration is causing grave anxiety. Here, Sir Philip said, is a salvage job which must be put in hand immediately. Much useful agricultural engineering work has already been done, but work needs to be greatly accelerated, otherwise "in a few years time there will be nothing left of the Ukamba Reserve". Concurrently, a social reorganization leading to a changed attitude of the African to his land must be carried through. Sir Philip sees most hope for soil conservation in the establishment of a landlord-tenant relationship, the landlord being the tribe as a whole, and the tenant the head of the family. Such a system would ensure the greatest possible security of tenure for the good cultivator and none for the incorrigible land miner. But he sees no short cut to the ultimate goal of restoring the land to a state of stable fertility.

\section{Merseyside Naturalists' Association}

The third war-time portfolio of the Merseyside Naturalists' Association, an attractively bound volume of two hundred and fifty pages comprising sixty-five pages of photographs and coloured plates and forty-three original articles, has been edited by Miss J. Linaker. It includes detailed accounts of regional bird-life at Mold, North Wales, by J. Lord and C. Swaine; Wigan and Leigh flashes, by G. Brown and T. Edmondson; Hoghton, by G. C. Miller; a Mersey shore pool, by F. J. Hartley ; St. Andrews, the Midlands and war areas of Italy and North Africa; the president, Philip Asheroft, describes his researches into the history of Martin Mere, the lake of 3,000 acres that once covered west Lancashire; Eric Hardy has a detailed account of the extinct and earliest known fauna of the north-west of England; and Mrs. E. G. Hardy describes how nestling hedge-sparrows were killed by a colony of brown ants. There is much that is of more than local interest. The raven is increasing its nesting range on the North Wales border, the cirl-bunting has definitely been established as a nesting bird in west Lancashire, while the colliery subsidence waters of south Lancashire are now known to be an important passage haunt of several rarer ducks, waders and wild swans.

\section{Bibliography of Seismology}

THE Bibliography of Seismology, 13, Nos. 14 and 15, Items 5564 to 5787, July 1943-June 1944, published by the Dominion Observatory, Ottawa, Canada, have just been received. In them are listed in full, occasionally with comments, papers and books from all parts of the world except Germany and Japan, dealing with pure and applied seismology. An interesting article listed in No. 14 is item 5579 by Centano-Grau, M., "Estudios sismologicos", Litografia del Comercio, pp. 555, 2 maps, 5 tab., Caracas, 1940, which gives a comprehensive review of many phases of seismology, and puts forward a theory of electrical causes for earthquakes of volcanic origin. The book contains a complete catalogue of earthquakes of Venezuela, and a study of the destructive shocks, including predictions of probable recurrences in different regions. In Nos. 14 and 15 numerous papers are listed dealing with rock bursts, chiefly in Canada and South Africa. One important paper is by Ernest A. Hodgson, "What is a Rock Burst ?" published by the Northern News, Kirkland Lake, September 9, 1943, after a radio talk by the author. Other papers are by J. Spalding and include such topics as "Description of a Rock Burst", "Theory and Practice of Ground Control", and "Theory of Rock-Pressure" (Kolar Gold Fields Mining and Metallurgical Society Bulletins, 8, No. 41, 153, Johannesburg, 1935-37). An interesting theoretical topic is listed as item 5709 in No. 15: Finch, R. H., "The seismic prelude to the 1942 Eruption of Mauna Loa" (Bulletin Seismological Society of America, 33, No. 4, 237 ; 1943). The paper presents evidence that the eruptions of Mauna Loa are preceded by pronounced seismic activity, but that this activity falls off for a month or more prior to the actual eruption. This paper may be considered a sequel to Harry $O$. Wood's paper in the same journal in 1915 on the 1914 activity. Items from Nature are listed in both parts of the bibliography.

\section{Announcements}

Prof. J. M. Mackintosh, professor of public health in the University of London and dean of the London School of Hygiene and Tropical Medicine, has been appointed a member of the Fuel and Power Advisory Council.

DR. J. G. DAvis, of the National Institute for Research in Dairying at Shinfield, near Reading, has been appointed scientific adviser to the Express Dairy Co., .Ltd., London. 